\title{
Alkyl and aryl sulfonyl p-pyridine ethanone oximes are efficient DNA photo-cleavage agents
}

\author{
Nicolaos-Panagiotis Andreou ${ }^{a}$, Konstantinos Dafnopoulos ${ }^{\text {a }}$, Christos Tortopidis ${ }^{\text {a }}$, Alexandros E. Koumbis ${ }^{\text {b }}$, \\ Maria Koffa ${ }^{c}$, George Psomas ${ }^{\mathrm{d}}$, Konstantina C. Fylaktakidou ${ }^{\mathrm{a}, *}$
}

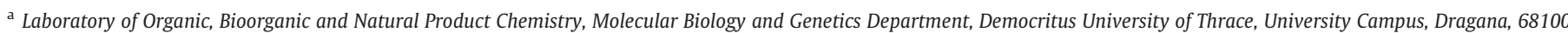
Alexandroupolis, Greece

${ }^{\mathrm{b}}$ Laboratory of Organic Chemistry, Chemistry Department, Aristotle University of Thessaloniki, 54124 Thessaloniki, Greece

c Laboratory of Cellular Biology and Cell Cycle, Molecular Biology and Genetics Department, Democritus University of Thrace, University Campus, Dragana, 68100 Alexandroupolis, Greece

d Laboratory of Inorganic Chemistry, Chemistry Department, Aristotle University of Thessaloniki, 54124 Thessaloniki, Greece

\section{A R T I C L E I N F O}

Article history:

Received 22 August 2015

Received in revised form 17 February 2016

Accepted 18 February 2016

Available online 27 February 2016

\section{Keywords:}

DNA photo-cleavage

DNA binding

Sulfonyl ketoximes

Sulfonyloxyl radicals

Photo-cleavage agents

\begin{abstract}
A B S T R A C T
Sulfonyloxyl radicals, readily generated upon UV irradiation of $p$-pyridine sulfonyl ethanone oxime derivatives, effectively cleave DNA, in a pH independent manner, and under either aerobic or anaerobic conditions. $p$ Pyridine sulfonyl ethanone oxime derivatives were synthesized from the reaction of $p$-pyridine ethanone oxime with the corresponding sulfonyl chlorides in good to excellent yields. All compounds, at a concentration of $100 \mu \mathrm{M}$, were irradiated at $312 \mathrm{~nm}$ for $15 \mathrm{~min}$, after incubation with supercoiled circular pBluescript KS II DNA and resulted in extended single- and double- strand cleavages. The cleavage ability was found to be concentration dependent, with some derivatives exhibiting activity even at nanomolar levels. Besides that, $p$-pyridine sulfonyl ethanone oxime derivatives showed good affinity to DNA, as it was observed with UV interaction and viscosity experiments with CT DNA and competitive studies with ethidium bromide. The compounds interact to CT DNA probably by non-classical intercalation (i.e. groove-binding) and at a second step they may intercalate within the DNA base pairs. The fluorescence emission spectra of pre-treated EB-DNA exhibited a significant or moderate quenching. Comparing with the known aryl carbonyloxyl radicals the sulfonyloxyl ones are more powerful, with both aryl and alkyl sulfonyl substituted derivatives to exhibit DNA photo-cleaving ability, in significantly lower concentrations. These properties may serve in the discovery of new leads for "on demand" biotechnological and medical applications.
\end{abstract}

(c) 2016 Elsevier B.V. All rights reserved.

\section{Introduction}

Light as an "on-off trigger" has long been used as a tool to promote and control reactions. It offers distinct advantages in several fields of chemistry, including biomedicine, where it has been employed in "on demand” therapeutic applications with profound benefits. Among others, cancer treatment has been realized using photodynamic therapy [1], combined in several cases with nanotechnological approaches [2].

Small synthetic organic molecules have been recognized as tools for targeting a variety of DNA structural features, aiming to cause cancer cell death [3]. Among DNA cleaving agents, those causing oxidative cleavage upon UV light activation are called "photo-cleavers" [4]. 0 Acyl oximes represent one such class of compounds [5-7], which yield photo-generated carbonyloxyl radicals (CRs) capable of causing oxidative DNA damage. However, their use is so far mainly limited to aryl

\footnotetext{
* Corresponding author.

E-mail address: kfylakta@mbg.duth.gr (K.C. Fylaktakidou).
}

conjugates, since the alkyl ones suffer rapid decarboxylation and produce less drastic radicals [8].

Sulfonyl ketoximes (SKs) are useful organic precursors, which, upon the Neber [9] or Beckmann [10] rearrangement reactions, provide access to medicinally interesting scaffolds [11]. However, very limited studies have been performed for the evaluation of the biological activity of SKs themselves [12]. In the field of photosensitive polymeric systems, SKs have found applications in microlithography, polymer, material and computer sciences [13], and are considered photo-acid generators. The production of the corresponding UV photo-generated sulfonyloxyl radicals (SRs), which abstract a hydrogen atom to form sulfonic acid derivatives, has been well documented [13].

In continuation of our interest in the chemistry and biology of oximes [7,14-17], we have decided to investigate the photo-activating behavior of SKs towards plasmid DNA. p-Pyridine ethanone oxime was selected as the model carrier scaffold of the sulfonyl moiety in order to facilitate comparison of the obtained results with the ones previously reported for the $p$-pyridine oxime and amidoxime ester conjugates [7]. Additionally, after evaluating the derivative which exhibits the best 
cleaving activity, the $p$-nitro-phenyl ester conjugate of $p$-pyridine ethanone oxime was also synthesized, allowing, thus, the direct reactivity comparison between sulfonyloxyl and carbonyloxyl radicals. A variety of both alkyl and aryl sulfonyl conjugates were prepared to further perform structure activity relationship (SAR) studies. Nevertheless, since SKs have the $S_{0} \rightarrow S_{1}$ and $S_{0} \rightarrow T_{1}$ transition states localized on the oxime moiety [18], similar activity is expected to be observed with other SKs as well, as long as they absorb at least partially at the wavelength of irradiation, and have some kind of affinity to DNA [3,4].

\section{Experimental}

\subsection{Materials, Physical Measurements and Instrumentation}

All commercially available reagent-grade chemicals and solvents were used without further purification. Dry solvents were prepared by literature methods and stored over molecular sieves. Calf thymus (CT) DNA, ethidium bromide (EB), $\mathrm{NaCl}$ and trisodium citrate were purchased from Sigma-Aldrich Co. DNA stock solution was prepared by dilution of CT DNA to buffer (containing $15 \mathrm{mM}$ trisodium citrate and $150 \mathrm{mM} \mathrm{NaCl}$ at $\mathrm{pH} 7.0$ ) followed by 3 day stirring and kept at $4{ }^{\circ} \mathrm{C}$ for no longer than two weeks. The stock solution of CT DNA gave a ratio of UV absorbance at 260 and $280 \mathrm{~nm}\left(\mathrm{~A}_{260} / \mathrm{A}_{280}\right)$ of 1.87, indicating that the DNA was sufficiently free of protein contamination [19]. The DNA concentration was determined by the UV absorbance at $260 \mathrm{~nm}$ after $1: 20$ dilution using $\varepsilon=6600 \mathrm{M}^{-1} \mathrm{~cm}^{-1}$ [20].

Melting points (mps) were measured on a Kofler hot-stage apparatus or a melting point meter M5000 Krüss, and are uncorrected. FT-IR spectra were obtained in a Perkin-Elmer 1310 spectrometer using potassium bromide pellets. NMR spectra were recorded on an Agilent $500 / 54$ ( $500 \mathrm{MHz}$ and $125 \mathrm{MHz}$ for $1 \mathrm{H}$ and $13 \mathrm{C}$ respectively) spectrometer using $\mathrm{CDCl}_{3}$, and/or DMSO- $d_{6}$ as solvent. J values are reported in $\mathrm{Hz}$. High resolution mass spectra (HRMS) were recorded on micrOTOF GCMS QP 5050 Shimadzu single-quadrupole mass spectrometer. Mass spectra were determined on a Shimadzu LCMS-2010 EV system under Electrospray Ionization (ESI) conditions. UV-vis spectra were recorded on a Hitachi U-2001 dual beam spectrophotometer. Fluorescence emission spectra were recorded in solution on a Hitachi F-7000 fluorescence spectrophotometer. Viscosity experiments were carried out using an ALPHA L Fungilab rotational viscometer equipped with an $18 \mathrm{~mL} \mathrm{LCP}$ spindle. Samples containing plasmid DNA were irradiated in a Macrovue 2011 transilluminator LKB BROMMA at $312 \mathrm{~nm}, \mathrm{~T}-15 . \mathrm{M}$ $90 \mathrm{~W}, 0.225 \mathrm{~W} / \mathrm{cm}^{2}$, and $10 \mathrm{~cm}$ distance.

All reactions were monitored on commercial available pre-coated TLC plates (layer thickness $0.25 \mathrm{~mm}$ ) of Kieselgel $60 \mathrm{~F}_{254}$. Silica gel Merck 60 (40-60 mM) has been used for column chromatography. Yields were calculated after recrystallization.

\subsection{General Procedure for the Synthesis of Ethanone Sulfonyl Oximes}

A solution of (E)-1-(pyridin-4-yl)ethanone oxime 1 [21] (274 mg, $2 \mathrm{mmol})$ in dry chloroform $(15 \mathrm{~mL})$ was cooled to $0{ }^{\circ} \mathrm{C}$ under an argon atmosphere. Triethylamine $(0.28 \mathrm{~mL}, 2 \mathrm{mmol})$ was added, followed by the required sulfonyl chloride $(2 \mathrm{mmol}$ ) and the mixture was stirred for $1-3 \mathrm{~h}$ allowing the temperature to slowly rise to $25^{\circ} \mathrm{C}$. The reaction was monitored by TLC and, upon completion, water $(70 \mathrm{~mL})$ was added and the mixture was extracted with dichloromethane $(2 \times 70 \mathrm{~mL})$. The combined organic extracts were dried $\left(\mathrm{Na}_{2} \mathrm{SO}_{4}\right)$ and concentrated under vacuum (rotary evaporator) to give a residue which was purified using column chromatography and a mixture of hexanes/ethyl acetate as eluent.

The same procedure was applied for the synthesis of the $p$-nitrobenzoyl oxime 15, but, instead of sulfonyl chloride, PNP-benzoyl chloride was used. Reaction time: $1 \mathrm{~h}$.

\subsection{Data of Sulfonyl Ketoximes 3-14 and Carbonyl Ketoxime $\mathbf{1 5}$}

\subsection{1. (E)-1-(pyridin-4-yl)ethanone 0-propylsulfonyl oxime (3)}

White crystals, yield $90 \%, \mathrm{mp} 135-136{ }^{\circ} \mathrm{C}$ (ethyl acetate/methanol); IR (KBr): 3045, 2973, 1621, 1372 and 1172 (SO) $\mathrm{cm}^{-1} ; 1 \mathrm{H} \mathrm{NMR}$ $\left(500 \mu \mathrm{Hz}, \mathrm{CDCl}_{3}\right) \delta 1.10(\mathrm{t}, J=7.5 \mathrm{~Hz}, 3 \mathrm{H}), 1.95$ (sext, $J=7.6 \mathrm{~Hz}, 2 \mathrm{H}$ ), $2.42(\mathrm{~s}, 3 \mathrm{H}), 3.38$ (t, $J=7.7 \mathrm{~Hz}, 2 \mathrm{H}), 7.57(\mathrm{~d}, J=6.2 \mathrm{~Hz}, 2 \mathrm{H}), 8.72$ $(\mathrm{d}, J=6.1 \mathrm{~Hz}, 2 \mathrm{H}) ; 13 \mathrm{C} \mathrm{NMR}\left(125 \mu \mathrm{Hz}, \mathrm{CDCl}_{3}\right) \delta 12.9,13.9,17.1,51.1$, 120.8, 141.0, 150.5, 162.1; HRMS (ESI) Calc $\mathrm{C}_{10} \mathrm{H}_{14} \mathrm{~N}_{2} \mathrm{O}_{3} \mathrm{~S}[\mathrm{M}+\mathrm{H}]^{+}$ 243.0798; found 243.0799.

\subsection{2. (E)-1-(pyridin-4-yl)ethanone O-decylsulfonyl oxime (4)}

Beige crystals, yield $58 \%, \mathrm{mp} 60{ }^{\circ} \mathrm{C}$ (ethyl acetate/methanol); IR (KBr): 2957, 2923, 2855, 1596, 1364 and 1169 (SO) $\mathrm{cm}^{-1}$; $1 \mathrm{H}$ NMR $\left(500 \mu \mathrm{Hz}, \mathrm{CDCl}_{3}\right) \delta 0.86(\mathrm{t}, J=6.7 \mathrm{~Hz}, 3 \mathrm{H}), 1.22-1.35(\mathrm{~m}, 12 \mathrm{H}), 1.45$ (quin, $J=7.4 \mathrm{~Hz}, 2 \mathrm{H}$ ), 1.90 (quin, $J=7.7 \mathrm{~Hz}, 2 \mathrm{H}$ ), $2.41(\mathrm{~s}, 3 \mathrm{H}$ ), 3.38 $(\mathrm{t}, J=7.8 \mathrm{~Hz}, 2 \mathrm{H}), 7.58(\mathrm{~d}, J=6.1 \mathrm{~Hz}, 2 \mathrm{H}), 8.71(\mathrm{~d}, J=5.9 \mathrm{~Hz}, 2 \mathrm{H})$; 13C NMR $\left(125 \mu \mathrm{Hz}, \mathrm{CDCl}_{3}\right) \delta 13.9,14.0,22.6,23.2,28.1,28.9,29.1$, 29.4, 31.8, 49.5, 120.8, 141.2, 150.4, 162.1; HRMS (ESI) Calc $\mathrm{C}_{17} \mathrm{H}_{28} \mathrm{~N}_{2} \mathrm{O}_{3} \mathrm{~S}[\mathrm{M}+\mathrm{H}]^{+}$341.1893; found 341.1894.

\subsection{3. (E)-1-(pyridin-4-yl)ethanone 0-hexadecylsulfonyl oxime (5)}

White crystals, yield $53 \%, \mathrm{mp} 66-68{ }^{\circ} \mathrm{C}$ (ethyl acetate/methanol); IR (KBr): 2957, 2921, 2851, 1366 and $1168(\mathrm{~S}=0) \mathrm{cm}^{-1} ; 1 \mathrm{H} \mathrm{NMR}$ $\left(500 \mu \mathrm{Hz}, \mathrm{CDCl}_{3}+\right.$ DMSO-d $\left.d_{6}\right) \delta 0.79(\mathrm{t}, J=6.7 \mathrm{~Hz}, 3 \mathrm{H}), 1.10-1.30$ (m, $24 \mathrm{H}$ ), 1.38 (quin, $J=7.3 \mathrm{~Hz}, 2 \mathrm{H}$ ), 1.79 (quin, $J=7.6 \mathrm{~Hz}, 2 \mathrm{H}$ ), 2.38 $(\mathrm{s}, 3 \mathrm{H}), 3.34(\mathrm{t}, J=7.7 \mathrm{~Hz}, 2 \mathrm{H}), 7.71(\mathrm{~d}, J=5.5 \mathrm{~Hz}, 2 \mathrm{H}), 8.70(\mathrm{~d}, J=$ $5.7 \mathrm{~Hz}, 2 \mathrm{H}) ; 13 \mathrm{C}$ NMR $\left(125 \mu \mathrm{Hz}, \mathrm{CDCl}_{3}+\right.$ DMSO- $\left._{6}\right) \delta 13.5,13.7,22.8$, 27.7, 28.5, 28.8, 28.9, 29.0, 29.13, 29.17, 29.19, 29.20, 29.21, 29.22, $31.5,49.0,120.5,140.7,150.0,161.8$; HRMS (ESI) Calc $\mathrm{C}_{23} \mathrm{H}_{40} \mathrm{~N}_{2} \mathrm{O}_{3} \mathrm{~S}$ $[\mathrm{M}+\mathrm{H}]^{+}$425.2832; found 425.2833 .

\subsection{4. (E)-1-(pyridin-4-yl)ethanone O-phenylsulfonyl oxime (6)}

Beige crystals, yield $93 \%, \mathrm{mp} 156.3{ }^{\circ} \mathrm{C}$ (ethyl acetate/ethanol); IR (KBr): 3048, 1592, 1377 and 1195 (SO) $\mathrm{cm}^{-1} ; 1 \mathrm{H} \mathrm{NMR}(500 \mu \mathrm{Hz}$, $\left.\mathrm{CDCl}_{3}\right) \delta 2.33(\mathrm{~s}, 3 \mathrm{H}), 7.42(\mathrm{bd}, J=4.6 \mathrm{~Hz}, 2 \mathrm{H}), 7.56(\mathrm{t}, J=7.9 \mathrm{~Hz}$, $2 \mathrm{H}), 7.66(\mathrm{t}, J=8.1 \mathrm{~Hz}, 1 \mathrm{H}), 8.02(\mathrm{~d}, J=8.1 \mathrm{~Hz}, 2 \mathrm{H}), 8.63(\mathrm{~d}, J=$ $4.6 \mathrm{~Hz}, 2 \mathrm{H})$; $13 \mathrm{C}$ NMR $\left(125 \mu \mathrm{Hz}, \mathrm{CDCl}_{3}\right) \delta 13.6,120.7,128.9,129.0$, 134.2, 135.2, 141.1, 150.3, 161.5; HRMS (ESI) Calc $\mathrm{C}_{13} \mathrm{H}_{12} \mathrm{~N}_{2} \mathrm{O}_{3} \mathrm{~S}$ $[\mathrm{M}+\mathrm{H}]^{+}$277.0641; found 277.0641.

\subsection{5. (E)-1-(pyridin-4-yl)ethanone 0-tosyl oxime (7) [22]}

Brown crystals, yield $89 \%, \mathrm{mp} 162.3^{\circ} \mathrm{C}$ (ethyl acetate/ethanol); IR (KBr): 1594, 1379 and 1195 (SO) $\mathrm{cm}^{-1}$; $1 \mathrm{H} \mathrm{NMR}\left(500 \mu \mathrm{Hz}, \mathrm{CDCl}_{3}\right) \delta$ 2.35 (s, 3H), $2.44(\mathrm{~s}, 3 \mathrm{H}), 7.37$ (d, $J=8.2 \mathrm{~Hz}, 2 \mathrm{H}), 7.54(\mathrm{~d}, J=6.2 \mathrm{~Hz}$, $2 \mathrm{H}), 7.91$ (d, $J=8.3 \mathrm{~Hz}, 2 \mathrm{H}), 8.67$ (d, $J=5.9 \mathrm{~Hz}, 2 \mathrm{H}) ; 13 \mathrm{C} \mathrm{NMR}$ $\left(125 \mu \mathrm{Hz}, \mathrm{CDCl}_{3}\right) \delta 13.6,21.7,121.2,128.9,129.7,132.0,142.6,145.6$, 149.0, 160.8; HRMS (ESI) Calc $\mathrm{C}_{14} \mathrm{H}_{14} \mathrm{~N}_{2} \mathrm{O}_{3} \mathrm{~S}[\mathrm{M}+\mathrm{H}]^{+}$291.0798; found 291.0798 .

2.3.6. (E)-1-(pyridin-4-yl)ethanone 0-[(4-nitrophenyl)sulfonyl] oxime (8)

Beige crystals, yield $90 \%, \mathrm{mp} 117-119{ }^{\circ} \mathrm{C}$ (ethyl acetate/ethanol); IR (KBr): 3105, 1531, 1381 and 1193 (SO) $\mathrm{cm}^{-1}$; $1 \mathrm{H} \mathrm{NMR}(500 \mu \mathrm{Hz}$, $\left.\mathrm{CDCl}_{3}\right) \delta 2.39(\mathrm{~s}, 3 \mathrm{H}), 7.42(\mathrm{~d}, J=5.4 \mathrm{~Hz}, 2 \mathrm{H}), 8.24(\mathrm{~d}, J=8.5 \mathrm{~Hz}, 2 \mathrm{H})$, $8.42(\mathrm{~d}, J=8.4 \mathrm{~Hz}, 2 \mathrm{H}), 8.68(\mathrm{~d}, J=5.4 \mathrm{~Hz}, 2 \mathrm{H}) ; 13 \mathrm{C} \mathrm{NMR}(125 \mu \mathrm{Hz}$, $\left.\mathrm{CDCl}_{3}\right) \delta 14.0,120.6,124.2,130.4,140.6,140.9,150.6,151.0,162.9$; HRMS (ESI) Calc $\mathrm{C}_{13} \mathrm{H}_{11} \mathrm{~N}_{3} \mathrm{O}_{5} \mathrm{~S}[\mathrm{M}+\mathrm{H}]^{+}$322.0492; found 322.0493 .

\subsection{7. (E)-1-(pyridin-4-yl)ethanone 0-[(4-methoxyphenyl)sulfonyl] oxime} (9)

White crystals, yield $74 \%, \mathrm{mp} 139-140{ }^{\circ} \mathrm{C}$ (ethyl acetate); IR ( $\left.\mathrm{KBr}\right)$ : 1596, 1376 and $1174(\mathrm{SO}) \mathrm{cm}^{-1}$; $1 \mathrm{H} \mathrm{NMR}\left(500 \mu \mathrm{Hz}, \mathrm{CDCl}_{3}\right) \delta 2.34(\mathrm{~s}$, $3 \mathrm{H}), 3.88(\mathrm{~s}, 3 \mathrm{H}), 7.02$ (d, $J=9.0 \mathrm{~Hz}, 2 \mathrm{H}), 7.52(\mathrm{~d}, J=6.2 \mathrm{~Hz}, 2 \mathrm{H})$, $7.96(\mathrm{~d}, J=9.0 \mathrm{~Hz}, 2 \mathrm{H}), 8.68(\mathrm{~d}, J=5.8 \mathrm{~Hz}, 2 \mathrm{H}) ; 13 \mathrm{C} \mathrm{NMR}(125 \mu \mathrm{Hz}$, $\left.\mathrm{CDCl}_{3}\right) \delta 13.6,55.7,114.3,121.1,126.3,131.2,142.4,149.2,160.7$, 
164.4; HRMS (ESI) Calc $\mathrm{C}_{14} \mathrm{H}_{14} \mathrm{~N}_{2} \mathrm{O}_{4} \mathrm{~S}[\mathrm{M}+\mathrm{H}]^{+}$307.0747; found 307.0747.

2.3.8. (E)-1-(pyridin-4-yl)ethanone O-[(4-(trifluoromethyl)phenyl] sulfonyl) oxime (10)

Off white crystals, yield $79 \%$, mp $115-116{ }^{\circ} \mathrm{C}$ (ethyl acetate/hexanes); IR (KBr): 3103, 3054, 1597, 1318, 1383 and 1196 (SO) $\mathrm{cm}^{-1}$; 1H NMR $\left(500 \mu \mathrm{Hz}, \mathrm{CDCl}_{3}\right) \delta 2.39(\mathrm{~s}, 3 \mathrm{H}), 7.53(\mathrm{~d}, J=3.8 \mathrm{~Hz}, 2 \mathrm{H}), 7.85$ $(\mathrm{d}, J=7.8 \mathrm{~Hz}, 2 \mathrm{H}), 8.17(\mathrm{~d}, J=7.8 \mathrm{~Hz}, 2 \mathrm{H}), 8.71(\mathrm{~d}, J=3.8 \mathrm{~Hz}, 2 \mathrm{H})$; 13C NMR $\left(125 \mu \mathrm{Hz}, \mathrm{CDCl}_{3}\right) \delta 13.9,120.7,122.6(\mathrm{q}, J=272 \mathrm{~Hz}), 126.2$ $(\mathrm{q}, J=3.7 \mathrm{~Hz}), 129.5,135.8(\mathrm{q}, J=34 \mathrm{~Hz}), 138.8,140.9,150.4,162.4$; HRMS (ESI) Calc $\mathrm{C}_{14} \mathrm{H}_{11} \mathrm{~F}_{3} \mathrm{~N}_{2} \mathrm{O}_{3} \mathrm{~S}[\mathrm{M}+\mathrm{H}]^{+}$345.0515; found 345.0518 .

\subsection{9. (E)-1-(pyridin-4-yl)ethanone O-[(4-bromophenyl)sulfonyl] oxime} (11)

Off white crystals, yield $79 \%$, mp $118-120{ }^{\circ} \mathrm{C}$ (ethyl acetate/hexanes); IR (KBr): 3086, 3015, 1569, 1176, 1379 and 1194 (SO) $\mathrm{cm}^{-1}$; $1 \mathrm{H} \mathrm{NMR}\left(500 \mu \mathrm{Hz}, \mathrm{CDCl}_{3}\right) \delta 2.37(\mathrm{~s}, 3 \mathrm{H}), 7.52(\mathrm{~d}, J=6.0 \mathrm{~Hz}, 2 \mathrm{H}), 7.72$ $(\mathrm{d}, J=8.5 \mathrm{~Hz}, 2 \mathrm{H}), 7.89$ (d, $J=8.6 \mathrm{~Hz}, 2 \mathrm{H}), 8.69(\mathrm{~d}, J=5.3 \mathrm{~Hz}, 2 \mathrm{H})$; 13C NMR $\left(125 \mu \mathrm{Hz}, \mathrm{CDCl}_{3}\right) \delta 13.8,121.1,129.8,130.4,132.5,134.1$, 142.1, 149.3, 161.6; HRMS (ESI) Calc $\mathrm{C}_{13} \mathrm{H}_{11} \mathrm{BrN}_{2} \mathrm{O}_{3} \mathrm{~S}[\mathrm{M}+\mathrm{H}]^{+}$ 354.9747; found 354.9747, 356.9726 .

2.3.10. (E)-1-(pyridin-4-yl)ethanone 0-[(4-chlorophenyl)sulfonyl] oxime (12)

Beige crystals, yield $72 \%, \mathrm{mp} 108.2^{\circ} \mathrm{C}$ (ethyl acetate); IR (KBr): 3092 , $3013,1592,1175,1382$ and 1194 (SO) $\mathrm{cm}^{-1} ; 1 \mathrm{H} \mathrm{NMR}\left(500 \mu \mathrm{Hz}, \mathrm{CDCl}_{3}\right)$ $\delta 2.37(\mathrm{~s}, 3 \mathrm{H}), 7.51(\mathrm{~d}, J=5.5 \mathrm{~Hz}, 2 \mathrm{H}), 7.55(\mathrm{~d}, J=8.5 \mathrm{~Hz}, 2 \mathrm{H}), 7.97(\mathrm{~d}$, $J=8.6 \mathrm{~Hz}, 2 \mathrm{H}), 8.69(\mathrm{~d}, J=5.8 \mathrm{~Hz}, 2 \mathrm{H}) ; 13 \mathrm{C} \mathrm{NMR}\left(125 \mu \mathrm{Hz}, \mathrm{CDCl}_{3}\right) \delta$ 13.8, 121.1, 129.5, 130.4, 133.5, 141.2, 142.1, 149.4, 161.6; HRMS (ESI) Calc $\mathrm{C}_{13} \mathrm{H}_{11} \mathrm{ClN}_{2} \mathrm{O}_{3} \mathrm{~S}[\mathrm{M}+\mathrm{H}]^{+}$311.0252; found 311.0258, 313.0227 .

\subsubsection{1. (E)-1-(pyridin-4-yl)ethanone 0-[(2,5-dichlorophenyl)sulfonyl]} oxime (13)

Beige crystals, yield $41 \%, \mathrm{mp} 106-108^{\circ} \mathrm{C}$ (ethyl acetate/ethanol); IR (KBr): 3083, 3060, 1593, 1389 and 1192 (SO) $\mathrm{cm}^{-1}$; $1 \mathrm{H} \mathrm{NMR}(500 \mu \mathrm{Hz}$, DMSO- $\left.d_{6}\right) \delta 2.47(\mathrm{~s}, 3 \mathrm{H}), 7.50(\mathrm{~d}, J=6.1 \mathrm{~Hz}, 2 \mathrm{H}), 7.82(\mathrm{~d}, J=8.6 \mathrm{~Hz}$, $1 \mathrm{H}), 7.89(\mathrm{dd}, J=8.6,2.6 \mathrm{~Hz}, 1 \mathrm{H}), 8.12(\mathrm{~d}, J=2.6 \mathrm{~Hz}, 1 \mathrm{H}), 8.66(\mathrm{~d}$, $J=6.1 \mathrm{~Hz}, 2 \mathrm{H}) ; 13 \mathrm{C}$ NMR $\left(125 \mu \mathrm{Hz}\right.$, DMSO-d $\left.d_{6}\right) \delta 14.5,121.4,130.8$, 132.1, 133.0, 134.4, 134.5, 136.5, 140.6, 150.8, 165.0; HRMS (ESI) Calc $\mathrm{C}_{13} \mathrm{H}_{10} \mathrm{Cl}_{2} \mathrm{~N}_{2} \mathrm{O}_{3} \mathrm{~S}[\mathrm{M}+\mathrm{H}]^{+}$344.9862; found 344.9864, 346.9832, 348.9801 .

\subsubsection{2. (E)-4-[1-(pyridin-4-yl)ethylideneaminooxysulfonyl]benzonitrile} (14)

Beige crystals, yield $54 \%, \mathrm{mp} 108.2^{\circ} \mathrm{C}$ (ethyl acetate); IR ( $\mathrm{KBr}$ ): 3097 , 3050, 2236, 1596, 1168, 1384 and 1195 (SO) $\mathrm{cm}^{-1} ; 1 \mathrm{H} \mathrm{NMR}(500 \mu \mathrm{Hz}$, $\left.\mathrm{CDCl}_{3}+\mathrm{DMSO}_{-} \mathrm{d}_{6}\right) \delta 2.36(\mathrm{~s}, 3 \mathrm{H}), 7.52(\mathrm{~d}, J=5.4 \mathrm{~Hz}, 2 \mathrm{H}), 8.05(\mathrm{~d}, J=$ $8.3 \mathrm{~Hz}, 2 \mathrm{H}), 8.15(\mathrm{~d}, J=8.4 \mathrm{~Hz}, 2 \mathrm{H}), 8.63(\mathrm{~d}, J=5.5 \mathrm{~Hz}, 2 \mathrm{H}) ; 13 \mathrm{C}$ NMR $\left(125 \mu \mathrm{Hz}, \mathrm{CDCl}_{3}+\right.$ DMSO$\left._{-} d_{6}\right) \delta 12.1,115.4,115.8,119.3,127.7$, 131.7, 137.0, 139.0, 148.2, 161.6; HRMS (ESI) Calc $\mathrm{C}_{14} \mathrm{H}_{11} \mathrm{~N}_{3} \mathrm{O}_{3} \mathrm{~S}$ $[\mathrm{M}+\mathrm{H}]^{+}$302.0594; found 302.0599.

\subsubsection{3. (E)-1-(pyridine-4-yl)ethan-1-one 0-(4-nitrobenzoyl)oxime (15)}

Off white crystals, yield $89 \%, \mathrm{mp} 205.1{ }^{\circ} \mathrm{C}$ (ethyl acetate); IR ( $\mathrm{KBr}$ ): $3110,3084,1744,1595 \mathrm{~cm}^{-1} ; 1 \mathrm{H} \mathrm{NMR}\left(500 \mu \mathrm{Hz}, \mathrm{CDCl}_{3}\right) \delta 2.55(\mathrm{~s}$, $3 \mathrm{H}), 7.70(\mathrm{~d}, J=5.8 \mathrm{~Hz}, 2 \mathrm{H}), 8.30(\mathrm{~d}, J=8.7 \mathrm{~Hz}, 2 \mathrm{H}), 8.37(\mathrm{~d}, J=$ $8.7 \mathrm{~Hz}, 2 \mathrm{H}), 8.75(\mathrm{~d}, J=5.8 \mathrm{~Hz}, 2 \mathrm{H}) ; 13 \mathrm{C} \mathrm{NMR}\left(125 \mu \mathrm{Hz}, \mathrm{CDCl}_{3}\right) \delta$ 14.3, 121.1, 123.9, 130.8, 134.1, 141.8, 150.5, 150.9, 161.6, 162.5; HRMS (ESI) Calc $\mathrm{C}_{14} \mathrm{H}_{11} \mathrm{~N}_{3} \mathrm{O}_{4}[\mathrm{M}+\mathrm{H}]^{+}$286.0822; found 286.0820 .

\subsection{DNA Cleavage Experiments}

2.4.1. Cleavage of Supercoiled Circular pBluescript KS II DNA by Sulfonyl Ketoximes

The reaction mixtures $(20 \mu \mathrm{L})$ containing supercoiled circular pBluescript KS II DNA stock solution (Form I, $50 \mu \mathrm{M} /$ base pair, $\sim 500 \mathrm{ng})$, compounds, and Tris buffer $(25 \mu \mathrm{M}, \mathrm{pH} 6.8)$ in Pyrex vials were incubated for $30 \mathrm{~min}$ at $37^{\circ} \mathrm{C}$, centrifuged, and then irradiated with UV light ( $312 \mathrm{~nm}, 90 \mathrm{~W}$ ) under aerobic conditions at room temperature for $15 \mathrm{~min}$. After addition of the gel-loading buffer (6X Orange DNA Loading Dye $10 \mathrm{mM}$ Tris- $\mathrm{HCl}$ (pH 7.6), 0.15\% orange G, $0.03 \%$ xylene cyanol FF, $60 \%$ glycerol, and 60 mM EDTA, by Fermentas), the reaction mixtures were loaded on a $1 \%$ agarose gel with ethidium bromide staining. The electrophoresis tank was attached to a power supply at a constant current ( $65 \mathrm{~V}$ for $1 \mathrm{~h}$ ). The gel was visualized by $312 \mathrm{~nm}$ UV transilluminator and photographed by an FB-PBC-34 camera vilber lourmat. Quantitation of DNA-cleaving activities was performed by integration of the optical density as a function of the band area using the program "Image J" available at the site http://rsb.info.nih.gov/ij/ download.html.

\subsubsection{Calculation of Single-strand Damage (ss)\% and Double-strand} Damage (ds)\%

ss\% and ds\% damage was calculated according to the following Eqs. (1) and (2).

$\mathrm{ss} \%=\frac{\text { Form II }}{(\text { Form I }+ \text { Form II }+ \text { Form III })} \times 100$

$\mathrm{ds} \%=\frac{\text { Form III }}{(\text { Form I }+ \text { Form II }+ \text { Form III })} \times 100$

As Form II we consider Form II of each series minus Form II of the irradiated control DNA. As Form I we consider Form I of each series.

\subsection{Interaction With CT DNA}

\subsubsection{Study With UV Spectroscopy}

The interaction of compounds $\mathbf{3}$ and $\mathbf{8}$ with CT DNA was studied by UV spectroscopy in order to investigate the possible binding modes to CT DNA and to calculate the binding constants to CT DNA ( $\left.\mathrm{K}_{\mathrm{b}}\right)$. The UV spectra of the compounds $\left(1 \times 10^{-4} \mathrm{M}\right)$ were recorded in the presence of CT DNA at diverse [compound]/[DNA] mixing ratios $(=r)$. Control experiments with DMSO were performed and no changes in the spectra of CT DNA were observed.

The binding constant, $\mathrm{K}_{\mathrm{b}}$, can be obtained by monitoring the changes in the absorbance at the corresponding $\lambda_{\max }$ with increasing concentrations of CT DNA and it is given by the ratio of slope to the $y$ intercept in plots [DNA] / $\left(\varepsilon_{\mathrm{A}}-\varepsilon_{\mathrm{f}}\right)$ versus [DNA], according to the Wolfe-Shimer equation [23]:

$\frac{[\mathrm{DNA}]}{\left(\varepsilon_{\mathrm{A}}-\varepsilon_{\mathrm{f}}\right)}=\frac{[\mathrm{DNA}]}{\varepsilon_{\mathrm{b}}-\varepsilon_{\mathrm{f}}}+\frac{1}{\mathrm{~K}_{\mathrm{b}}\left(\varepsilon_{\mathrm{b}}-\varepsilon_{\mathrm{f}}\right)}$

where [DNA] is the concentration of DNA in base pairs, $\varepsilon_{A}=A_{\text {obsd }} /$ [compound], $\varepsilon_{\mathrm{f}}=$ the extinction coefficient for the free compound and $\varepsilon_{\mathrm{b}}=$ the extinction coefficient for the compound in the fully bound form.

\subsubsection{Viscometry}

Viscosity experiments were carried out using an ALPHA L Fungilab rotational viscometer equipped with an $18 \mathrm{mLLCP}$ spindle and the measurements were performed at $100 \mathrm{rpm}$. The viscosity of DNA ([DNA] = $0.1 \mathrm{mM}$ ) in buffer solution (150 mM NaCl and $15 \mathrm{mM}$ trisodium citrate at $\mathrm{pH}$ 7.0) was measured in the presence of increasing amounts of the compounds (up to the value of $r=0.35$ ). All measurements were 
performed at room temperature. The obtained data are presented as $\left(\eta / \eta_{0}\right)^{1 / 3}$ versus $r$, where $\eta$ is the viscosity of DNA in the presence of the compound, and $\eta_{0}$ is the viscosity of DNA alone in buffer solution.

\subsubsection{Competitive Studies With EB}

The competitive studies of each compound with EB were investigated with fluorescence emission spectroscopy in order to examine whether the compound can displace EB from its DNA-EB complex. The DNAEB complex was prepared by adding $20 \mu \mathrm{M}$ EB and $26 \mu \mathrm{M}$ CT DNA in buffer ( $150 \mathrm{mM} \mathrm{NaCl}$ and $15 \mathrm{mM}$ trisodium citrate at pH 7.0). The possible intercalating effect of the compounds was studied by adding a certain amount of a solution of the compound step by step into a solution of the DNA-EB complex. The influence of the addition of each compound to the DNA-EB complex solution was monitored by recording the variation of fluorescence emission spectra with excitation wavelength at $540 \mathrm{~nm}$.

The Stern-Volmer constant $\left(\mathrm{K}_{\mathrm{Sv}}\right)$ is used to evaluate the quenching efficiency for each compound according to the Stern-Volmer equation [24]:

$\frac{\text { Io }}{\mathrm{I}}=1+\mathrm{K}_{\mathrm{SV}}[\mathrm{Q}]$

where Io and I are the emission intensities in the absence and the presence of the quencher, respectively, [Q] is the concentration of the quencher (compounds $\mathbf{3}$ and $\mathbf{8}$ ); $\mathrm{K}_{\mathrm{SV}}$ is obtained from the SternVolmer plots by the slope of the diagram Io/I versus [Q]. Subsequently, the quenching constant $\mathrm{k}_{\mathrm{q}}$ may be calculated by the equation:

$\mathrm{K}_{\mathrm{SV}}=\mathrm{k}_{\mathrm{q}} \tau_{\mathrm{o}}$

where $\tau_{\mathrm{o}}=$ the average fluorescence lifetime of the EB-DNA system.

\section{Results and Discussion}

\subsection{Chemistry}

Photolysis causes homolytic cleavage of the $\mathrm{N}-\mathrm{O}$ bond of SKs and production of iminyl and sulfonyloxyl radicals (Scheme 1). As it has been demonstrated the iminyl radical may abstract a hydrogen atom to give an imine, which is further hydrolyzed to give the corresponding ketone. The same ketone is obtained when the iminyl radical reacts with molecular oxygen. Finally, a third option is its dimerization to a bisalkylidene hydrazine derivative. On the other hand, the SR abstracts a hydrogen atom and gives the corresponding acid [13].

The mixture of oxime sulfonyl esters photo-cleaved material is expected to contain iminyl and sulfonyloxyl radicals, which, potentially, are both capable of attacking DNA, under various mechanisms. Since there is no precedent of SRs acting as DNA photo-cleaving agents, we wish to provide data which correspond to the reactivity of SRs themselves. For this reason we have synthesized derivatives 3-14 in order to establish a structure-activity relationship study within the SRs series. Additionally, based on the fact that derivative $\mathbf{8}$ exhibited the best activity, we have synthesized its carbonyl analogue (15), in order to compare the reactivity of the sulfonyl and the carbonyl radicals of similar origin.

Compounds 3-14 were synthesized in good yields, as a single product, upon the reaction of $p$-pyridine ethanone oxime $\mathbf{1}$ [21] with the corresponding alkyl or aryl sulfonyl chlorides $\mathbf{2 a - 1}$ in dry $\mathrm{CHCl}_{3}$, in the presence of $\mathrm{Et}_{3} \mathrm{~N}$ and under an argon atmosphere (Scheme 2).

Compound 15 was similarly obtained, using the corresponding benzoyl chloride, Scheme 3.

All these compounds are new, with the exception of 7, which has been previously reported [22].

\subsection{DNA Cleavage Studies}

DMF solutions of SKs 3-14 $(100 \mu \mathrm{M})$ were mixed with a Tris buffer solution $(25 \mu \mathrm{M}, \mathrm{pH}=6.8)$ containing the supercoiled circular pBluescript KS II DNA (Form I) and this mixture was irradiated with UV light (312 nm) at room temperature for $15 \mathrm{~min}$, under aerobic conditions. Plasmid DNA was analyzed by gel electrophoresis on $1 \%$ agarose stained with ethidium bromide, Fig. 1. All experiments were performed at least three times. None of the tested compounds showed any activity towards DNA in the absence of UV irradiation.

In the presence of compounds 3-14 the supercoiled plasmid DNA (Form I) sustained single-stranded (ss) nicks of the double helix, generating the relaxed circular DNA (Form II) found in all experiments, whereas the linear DNA (Form III) was formed as well, generated by double-stranded (ds) nicks, Fig. 1.

The results presented in Fig. 1 show that most of the aryl SKs are in general considerably reactive. The most important observation is that alkyl SRs are also effective, and, comparing to the aryl ones, they are similarly efficient at the given concentration, contrary to what was observed for the carbonyl analogues [7,8]. As for the aromatic ones, a SAR study revealed that lack of substitution on the aromatic ring (6) results in reduced activity. The activity also decreases when the $\mathrm{CH}_{3}$ group is replaced with the electron withdrawing $\mathrm{CF}_{3}$ group ( $\mathbf{7}$ and $\mathbf{1 0}$, respectively). Additionally, regarding the $p$-halogenated compounds, the bromo-derivative $\mathbf{1 1}$ is not as efficient comparing to the chloro-one $\mathbf{1 2}$ [4], whereas the dichloro-derivative $\mathbf{1 3}$ was the less reactive. Calculation of the energies of the $\mathrm{N}-\mathrm{O}$ bonds of these SKs indicates that their variation lies within $\sim 2 \mathrm{Kcal} / \mathrm{mol}(45.4-47.7 \mathrm{Kcal} / \mathrm{mol})$.

The observations that a) the energy provided by UV irradiation is more than sufficient for the cleavage of all $\mathrm{N}-\mathrm{O}$ bonds; $\mathrm{b}$ ) the length of the aliphatic chain is almost irrelevant to the activity; c) the substituents of the aromatic ring with electron donating effect ( $\mathbf{7}$ and $\mathbf{9}$ ) and electron withdrawing effect (8) have approximately the same activity (Form II + Form III); and d) all aromatic substituents with electron withdrawing effects have not the same activity ( 8 and 10-14) shows that the variations of activity might also be dependable on affinity DNA interactions of the sulfonyl conjugates. This is in accordance to previously reported conclusions regarding the dependence of DNA cleavage mechanism on the structure of the photo-cleavage agent, primarily because of the geometrical requirements for $\mathrm{H}$-abstraction reactions [4a].

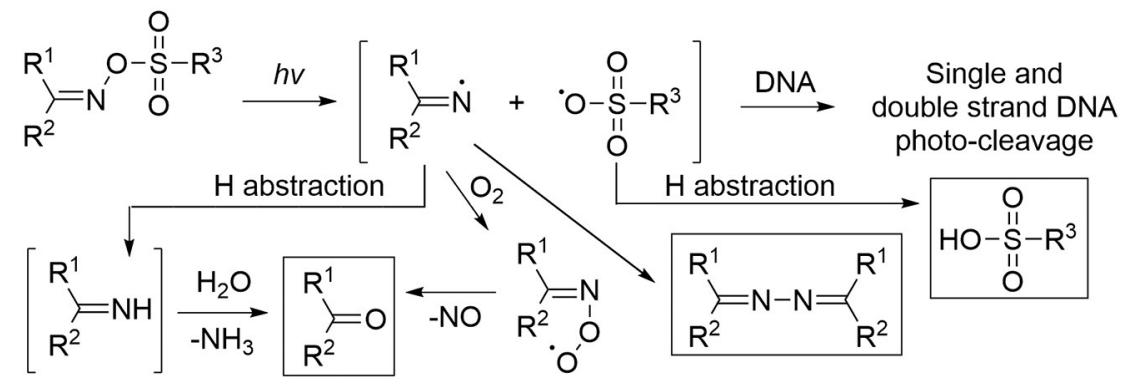

Scheme 1. The fate of radicals generated by the photo-cleavage of the $\mathrm{N}-\mathrm{O}$ bond of oxime sulfonyl esters. 
<smiles></smiles>

2a, 3: $\mathrm{R}=\mathrm{C}_{3} \mathrm{H}_{7-}^{-}$

2b, 4: $\mathrm{R}=\mathrm{C}_{10} \mathrm{H}_{21}$

2c, $5: \mathrm{R}=\mathrm{C}_{16} \mathrm{H}_{33^{-}}$

2d, 6: $\mathrm{R}=\mathrm{C}_{6} \mathrm{H}_{5-}$

2e, $7: \mathrm{R}=\mathrm{p}-\mathrm{CH}_{3}-\mathrm{C}_{6} \mathrm{H}_{4}$ -

2f, 8: $\mathrm{R}=\mathrm{p}-\mathrm{NO}_{2}-\mathrm{C}_{6} \mathrm{H}_{4}-$

2g, 9: $\mathrm{R}=\mathrm{p}-\mathrm{CH}_{3} \mathrm{O}-\mathrm{C}_{6} \mathrm{H}_{4}$

2h, 10: $\mathrm{R}=\mathrm{p}-\mathrm{CF}_{3}-\mathrm{C}_{6} \mathrm{H}_{4}-$

2i, 11: $\mathrm{R}=\mathrm{p}-\mathrm{Br}-\mathrm{C}_{6} \mathrm{H}_{4}-$

2j, 12: $\mathrm{R}=\mathrm{p}-\mathrm{Cl}-\mathrm{C}_{6} \mathrm{H}_{4}-$

2k, 13: $\mathrm{R}=2,5-\mathrm{Cl}_{2}-\mathrm{C}_{6} \mathrm{H}_{3}$ -

2I, 14: $\mathrm{R}=\mathrm{p}-\mathrm{CN}-\mathrm{C}_{6} \mathrm{H}_{4}-$

Scheme 2. Synthesis of $p$-pyridine-ethanone oxime sulfonyl esters 3-14. Reagents and conditions: $\mathrm{RSO}_{2} \mathrm{Cl}$ (1.1 eq.), dry Et $\mathrm{N}$ (1.1 eq.), dry $\mathrm{CHCl}_{3}, 0^{\circ} \mathrm{C}$ to r.t., $1-3 \mathrm{~h}, 41-93 \%$.

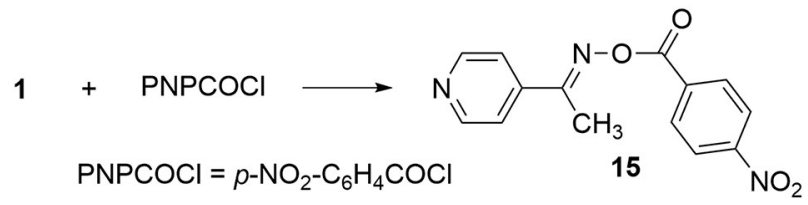

Scheme 3. Synthesis of the p-pyridine-ethanone PNP oxime 15. Reagents and conditions: PNPCOCl (1.1 eq.), dry Et 3 N (1.1 eq.), dry $\mathrm{CHCl}_{3}, 0{ }^{\circ} \mathrm{C}$ to r.t., $1 \mathrm{~h}, 89 \%\left(\mathrm{PNP}=p-\mathrm{NO}_{2}-\mathrm{C}_{6} \mathrm{H}_{4^{-}}\right)$.

A high ratio of ds to ss cleavages is a very important characteristic of DNA cleaving ability [25], since ds cleavages are more difficult to be repaired and may trigger self-programmed cell death. The UV generated SRs cause ss and ds cleavages, with the one derived from $p$-pyridine $p$ nitrophenyl sulfonyl ethanone oxime $\mathbf{8}$ yielding the best ratio of double- to single-strand damages [Fig. 1(A), Lane 8 and Fig. 1(B)]. Moreover, compared to the $p$-pyridine $p$-nitrobenzoyl oxime and amidoxime derivatives, the sulfonyl ones were found to exhibit a superior effect on cleavage: approximately 10 -fold lower concentrations were sufficient to lead to the same activity, along with similar ds/ss ratio cleavage (the effective concentration was $100 \mu \mathrm{M}$ and $1000 \mu \mathrm{M}$, respectively) [7]. This is in accordance with previous literature kinetic results where SRs are reported to be more reactive compared to CRs [26]. The role of the $p$-nitro-phenyl conjugate was also found to be important in both types of radicals $[4,7,27]$. DNA photo cleavage of carbonyl compound
15 was $86( \pm 5.8) \%$, including a $~ 3 \%$ of double-strand cleavage, at a concentration of $100 \mu \mathrm{M}$ [Fig. 2(A), Lane 9]. Although both 8 and $\mathbf{1 5}$ completely consume supercoiled plasmid DNA at the given concentration, sulfonyl ester $\mathbf{8}$ causes many more nicks, which eventually leads to the formation of linear DNA and a high ds/ss ratio.

Furthermore, we have also examined the lowest concentration which is sufficient for the $50 \%$ cleavage of the supercoiled plasmid DNA caused by each one of compounds 3-8. The results at concentrations of 10 and $1 \mu \mathrm{M}$ are given in Fig. 2(A) and (B), respectively. The diagram with the average cleavage for all experiments is depicted in Fig. 2(C). All three aromatic sulfonic conjugates exhibit good cleavage ability $(\sim 70-80 \%)$ at a concentration of $10 \mu \mathrm{M}$, whereas the aliphatic ones were found less reactive at both concentrations.

In brief, the cleavage caused by SKs is concentration dependent. Comparing the activity of carbonyl analogue $\mathbf{1 5}$ at a concentration of $100 \mu \mathrm{M}$ with the sulfonyl analogue 8 at a concentration of $10 \mu \mathrm{M}$ we conclude that the latter has about the same activity in approximately 10 -fold lower concentration $[86( \pm 5.8) \%$ and $77.5( \pm 1.1) \%$, respectively], Fig. 2(A) lanes 8 and 9. Compound 8 is effective for 50\% DNA photo-cleavage in a concentration of approximately $1 \mu \mathrm{M}$. Most importantly, according to these results all compounds are expected to have some activity even in the nanomolar range.

Mechanistic studies performed with compound 8 (Fig. 3, left part) showed that SKs can react under anaerobic conditions (Lane 4) and that the mode of action under aerobic conditions most probably involves hydroxyl radicals and singlet oxygen (reaction with DMSO-Lane 5 and $\mathrm{NaN}_{3}$-Lane 6, respectively). Nevertheless, the cleavage of plasmid DNA is not enhanced when $\mathrm{D}_{2} \mathrm{O}$ was used as solvent (Lane 7). These results indicate that not a single mechanistic pathway is implicated in the cleavage. Additional experiments to clarify the behavior of the system are in due course. Finally, a variation of $\mathrm{pH}$ (range 5-8) does not affect the photo-cleavage activity (Fig. 2, right part, Lanes 8-11, respectively).

The ability of SKs to act under anaerobic conditions and acidic $\mathrm{pH}$ may be very useful in the treatment of solid tumors were hypoxic conditions as well as low acidity dominate [28].

\subsection{DNA Binding Studies}

The interaction of SKs with CT DNA, which proves the affinity of SKs with DNA, was examined by UV spectroscopic titrations and DNA

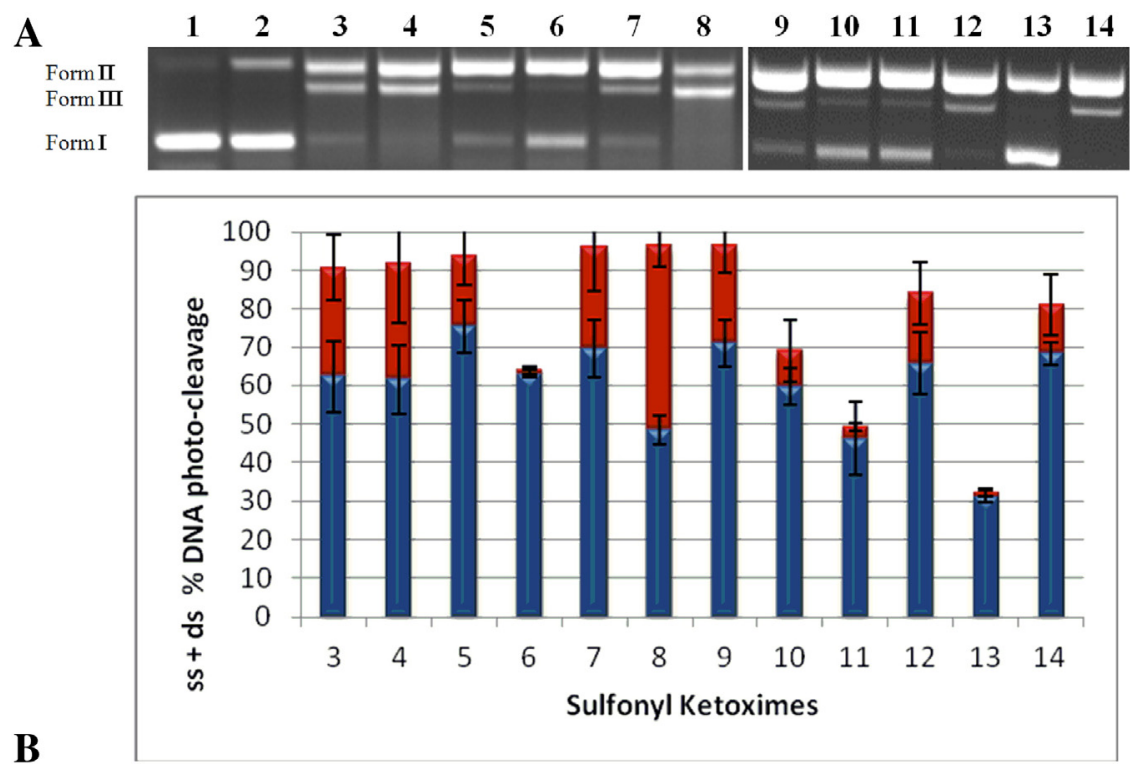



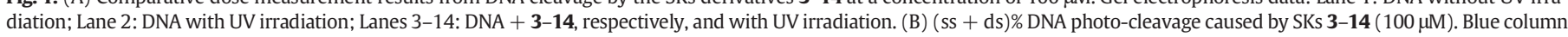
ss\%, red column ds\%. 

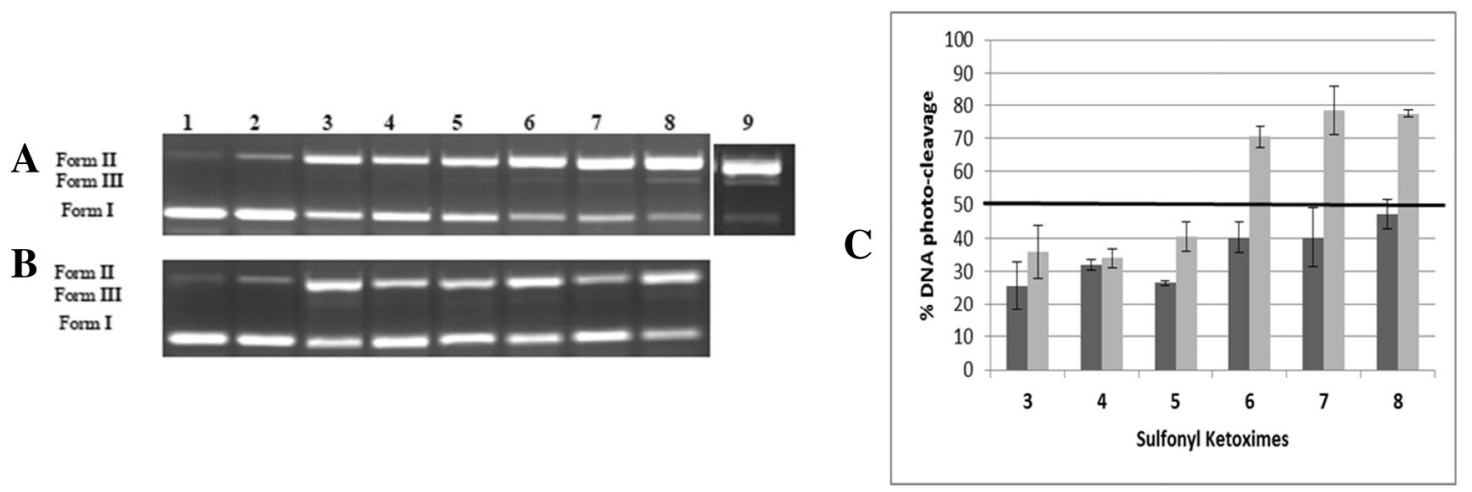

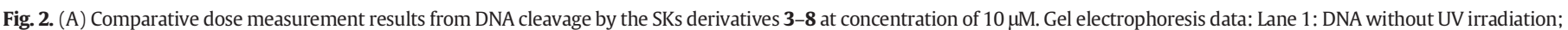

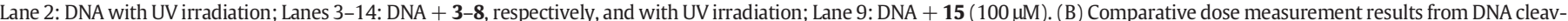

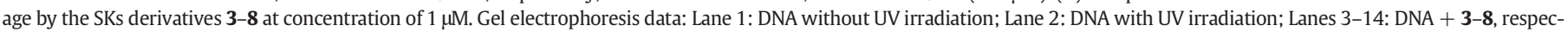
tively, and with UV irradiation. (C) \% DNA photo-cleavage caused by SKs 3-8 (1 $\mu \mathrm{M}$ and $10 \mu \mathrm{M}$, dark gray and light gray, respectively).

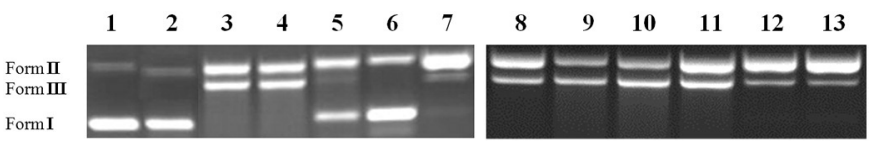

Fig. 3. Gel electrophoresis data. Left part: Mechanistic studies involved at the DNA cleavage by derivative $8(100 \mu \mathrm{M})$. Lane 1: DNA without UV irradiation; Lanes 2-13: DNA with UV irradiation; Lane 3: DNA + 8; Lane 4: DNA + $8+$ argon; Lane 5: DNA + $8+$ DMSO (20\%); Lane 6: DNA $8+\mathrm{NaN}_{3}$; Lane 7: DNA + $8+\mathrm{D}_{2} \mathrm{O}$. Right part: Effect of pH. Lanes 8-13: DNA $+\mathbf{8}$ at pH 5, 6, 7, 8, 9, and 10, respectively.

viscosity measurements and was carried out representatively for the alkyl derivative $\mathbf{3}$ and the aryl one $\mathbf{8}$, which exhibited the best activity. The slight hypochromism (2\% for $\mathbf{3}$ and $3 \%$ for $\mathbf{8}$ ) observed in the UV spectra of the compounds in the presence of increasing amounts of CT DNA (Fig. 4) is indicative of the existing interaction.

The binding constant of the compounds with CT DNA $\left(K_{b}\right)$ was calculated by the Wolfe-Shimer equation (Eq. (3)) [23] and plots \{[DNA] / $\left.\left(\varepsilon_{\mathrm{A}}-\varepsilon_{\mathrm{f}}\right)\right\}$ versus [DNA] (Insets in Fig. 4). The $\mathrm{K}_{\mathrm{b}}$ value of $\mathbf{3}\left[\mathrm{K}_{\mathrm{b}}=\right.$ $\left.4.82( \pm 0.25) \times 10^{5} \mathrm{M}^{-1}\right]$ was much higher than that of $8\left[\mathrm{~K}_{\mathrm{b}}=\right.$ $\left.2.44( \pm 0.10) \times 10^{5} \mathrm{M}^{-1}\right]$, suggesting that 3 exhibits higher affinity than 8 for CT DNA. These $K_{b}$ values are of the same order to that of classic DNA-intercalator ethidium bromide $(\mathrm{EB})\left(\mathrm{K}_{\mathrm{b}}=1.23 \times 10^{5} \mathrm{M}^{-1}\right)$ as previously reported by our group [29].

However, it is generally believed that it is not quite safe to propose the exact mode of binding to CT DNA merely from UV spectroscopic titration studies [30]. Thus, the viscosity of a CT DNA solution $(0.1 \mathrm{mM})$ was monitored upon addition of increasing amounts of the compounds $\mathbf{3}$ and $\mathbf{8}$ (up to the value of $\mathrm{r}=0.35$ ) (Fig. 5). Initially and up to $\mathrm{r}$ value of
0.12 , the viscosity did not exhibit any appreciable change in the presence of the compounds; for higher concentrations, however, the viscosity presented a significant increase.

Considering the overall changes of the DNA viscosity in the presence of compounds $\mathbf{3}$ and $\mathbf{8}$, we may suggest that, initially, the compounds interact to CT DNA probably by non-classical intercalation (i.e. groovebinding) and at a second step they may intercalate within the DNA base pairs [31]. This behavior may elucidate the findings from the UV spectroscopic studies.

The ability of the compounds to displace EB from the EB-DNA complex may shed light in their intercalating ability. The competition between compounds $\mathbf{3}$ and $\mathbf{8}$ with EB for the intercalation sites of DNA was monitored by fluorescence emission spectroscopy with $\lambda_{\text {excitation }}=$ $540 \mathrm{~nm}$. The fluorescence emission spectra of pre-treated EB-DNA ( $[\mathrm{EB}]=20 \mu \mathrm{M},[\mathrm{DNA}]=26 \mu \mathrm{M})$ as recorded in the presence of increasing amounts of compounds $\mathbf{3}$ or $\mathbf{8}$ [Fig. 6(A) and (B)] exhibit a significant or moderate quenching [ $60.2 \%$ for 3 and $48 \%$ for $\mathbf{8}$, Fig. 6(C)], respectively. This quenching is due to the ability of the compounds to displace EB from the DNA-EB complex and indirectly reveals that their interaction with CT DNA via an intercalative mode may exist [31].

Furthermore, the observed quenching is in good agreement ( $\mathrm{R}=$ 0.99) with the linear Stern-Volmer equation (Eq. (4)) [24]. The values of the Stern-Volmer constant $\left(\mathrm{K}_{\mathrm{SV}}\right)$ as calculated from the SternVolmer plots (Insets in Fig. 6) are $6.07( \pm 0.18) \times 10^{4} \mathrm{M}^{-1}$ for 3 and $3.72( \pm 0.10) \times 10^{4} \mathrm{M}^{-1}$ for $\mathbf{8}$; they may be considered rather high and verify the tight binding of compounds $\mathbf{3}$ and $\mathbf{8}$ to DNA $[29,32]$. Taking $\tau_{0}=23 \mathrm{~ns}$ as the fluorescence lifetime of EB-DNA system [33], the quenching constants of the compounds as calculated
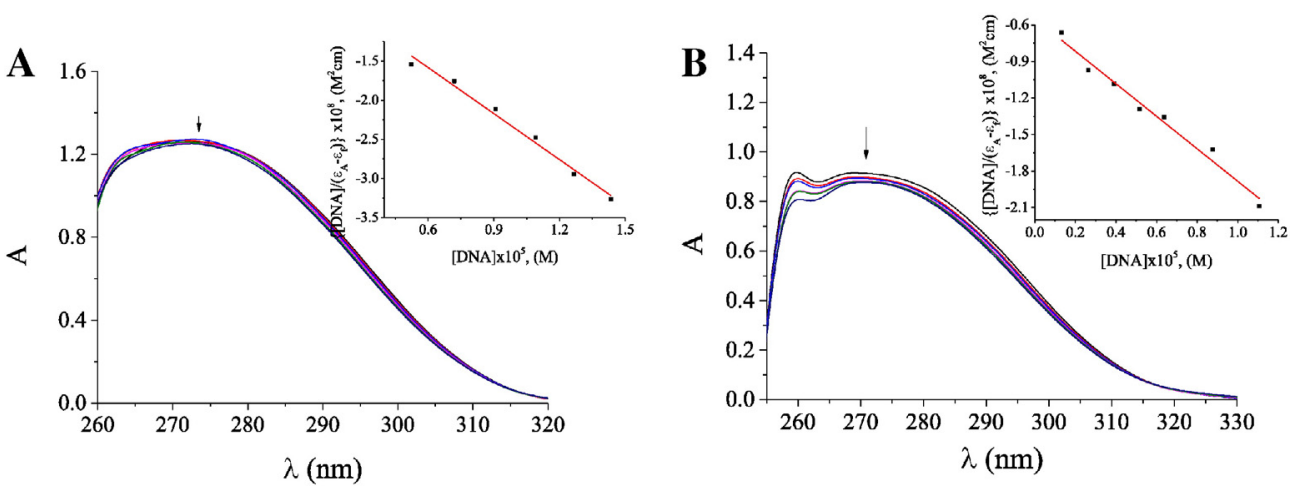

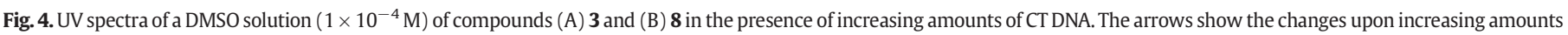
of CT DNA. Insets: Plot of $\frac{[D N A]}{\left(\varepsilon_{A}-\varepsilon_{f}\right)}$ versus [DNA]. 


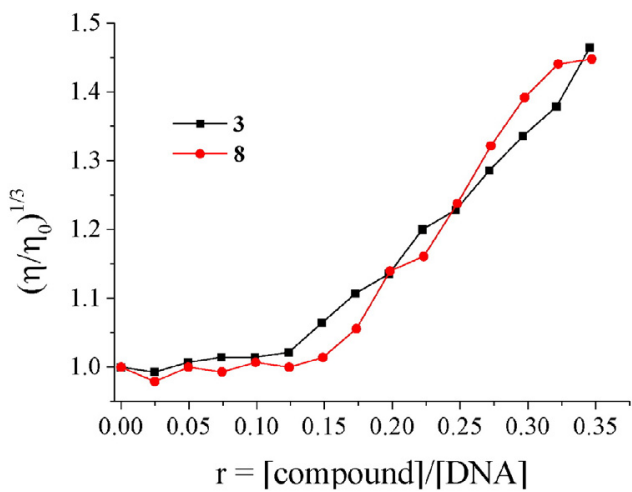

Fig. 5. Relative viscosity $\left(\eta / \eta_{\mathrm{o}}\right)^{1 / 3}$ of CT DNA $(0.1 \mathrm{mM})$ in buffer solution $(150 \mathrm{mM} \mathrm{NaCl}$ and $15 \mathrm{mM}$ trisodium citrate at pH 7.0) in the presence of compounds $\mathbf{3}$ and $\mathbf{8}$ at increasing amounts $(r=$ [compound $] /[\mathrm{DNA}])$.

with Eq. (5) are $\mathrm{k}_{\mathrm{q}(\mathbf{3})}=2.64( \pm 0.08) \times 10^{12} \mathrm{M}^{-1} \mathrm{~s}^{-1}$ and $\mathrm{k}_{\mathrm{q}(\mathbf{8})}=$ $1.62( \pm 0.04) \times 10^{12} \mathrm{M}^{-1} \mathrm{~s}^{-1}$; the values of the $\mathrm{k}_{\mathrm{q}}$ constants are significantly higher than $10^{10} \mathrm{M}^{-1} \mathrm{~s}^{-1}$ suggesting, thus, the quenching via a static mechanism [34].

A current study from our group, concerning the photo-cleavage of sulfonyl amidoximes [35], show results which are in general agreement with the observations of the present. However, SKs presented herein show better activity. The reasons may be that, at least in comparable derivatives, SKs show lower $\mathrm{N}-\mathrm{O}$ bond energy $(\sim 5 \mathrm{Kcal} / \mathrm{mol})$, as well as better intercalation as it was measured in binding affinity studies.

\section{Conclusions}

We have shown that SRs are effective DNA photo-cleaving agents. The herein provided experimental results evident a superiority of SRs compared to the known CRs as DNA photo-cleavers. SK $\mathbf{8}$ had similar ratio of ds to ss cleavage, in an approximately 10 -fold lower concentration than a comparable oxime ester.

Additionally, another factor differentiating SRs from CRs, is that alkyl SRs are very potent DNA photo-cleavers. This property was not so far observed for the carbonyl derivatives. SAR and DNA binding affinity studies within the 4-pyridine SK series revealed that the aliphatic SK 3 exhibited better affinity to DNA than the aromatic SK 8, but approximately the same total photo-cleavage ability, although with a lower ratio of ds to ss cleavage.

Sulfonyl ketoximes are organic compounds easily accessible in large scale from ketone derived oximes, and are stable in the absence of light for prolonged periods of time. The DNA cleavage is concentration dependent and occurs simply by irradiation without the need of external additives. 4-Pyridine ethanone oxime has been used as a model compound and it proved the efficacy of the SRs as novel DNA photocleavage agents, in concentrations close to the nanomolar scale.
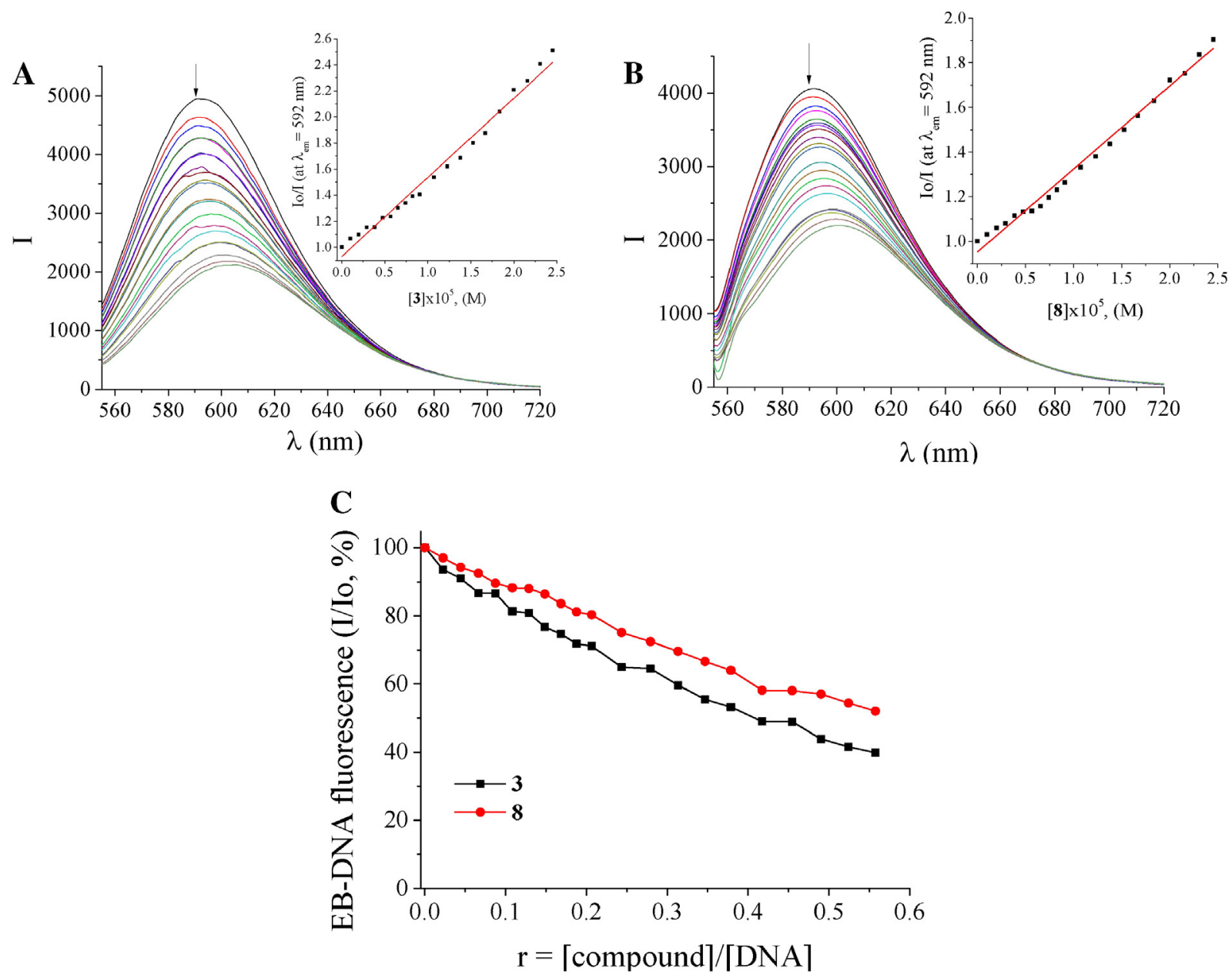

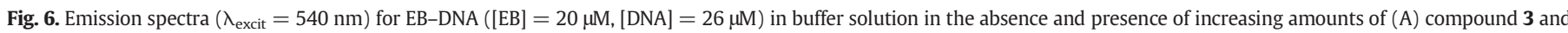

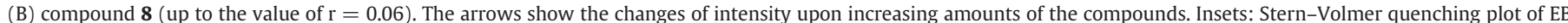

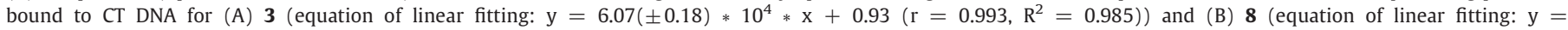

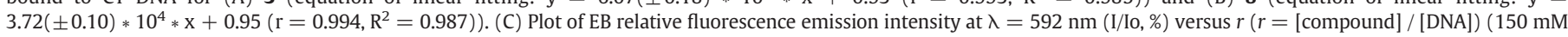
$\mathrm{NaCl}$ and $15 \mathrm{mM}$ trisodium citrate at $\mathrm{pH}=7.0$ ) in the presence of compound $\mathbf{3}$ and $\mathbf{8}$ (up to $39.8 \%$ of the initial EB-DNA fluorescence intensity for $\mathbf{3}$ and $52 \%$ for $\mathbf{8}$ ). 
The possibility of introducing a variety of properly designed SKs which, depending on their individual DNA interactions, could yield highly reactive SRs, may be fruitful in the fields of pharmacy, molecular biology and medicine. Thus, enriching the pool of possible applications with more powerful weapons, capable of acting at various pHs and under aerobic or anaerobic conditions, may provide novel biotechnological and therapeutic approaches for anticancer and antimicrobial therapies.

\section{Acknowledgments}

We thank Assoc. Prof. A. K. Zarkadis (Univ. of Ioannina, Chemistry Department) and Dr. P. Varras and Dr. P. Gritzapis for the calculation of the $\mathrm{N}-\mathrm{O}$ bond energies of the compounds. The authors declare no competing financial interest.

\section{References}

[1] a) Y. Li, H. Dong, Y. Li, D. Shi, Graphene-based nanovehicles for photodynamic medical therapy, Int. J. Nanomedicine 10 (2015) 2451-2459;

b) S.S. Lucky, K.C. Soo, Y. Zhang, Nanoparticles in photodynamic therapy, Chem. Rev. 115 (2015) 1990-2042

c) D. Bechet, S.R. Mordon, F. Guillemin, M.A. Barberi-Heyob, Photodynamic therapy of malignant brain tumours: a complementary approach to conventional therapies, Cancer Treat. Rev. 40 (2014) 229-241.

[2] a) X. Yi, F. Wang, W. Qin, X. Yang, J. Yuan, Near-infrared fluorescent probes in cancer imaging and therapy: an emerging field, Int. J. Nanomedicine 9 (2014) $1347-1365$

b) A.M. Pekkanen, M.R. Dewitt, M.N. Rylander, Nanoparticle enhanced optical imaging and phototherapy of cancer. J. Biomed. Nanotechnol. 36 (2014) 1677-1712.

[3] a) A. Ali, S. Bhattacharya, DNA binders in clinical trials and chemotherapy, Bioorg. Med. Chem. 22 (2014) 4506-4521

b) M. Sirajuddin, S. Ali, A. Badshah, Drug-DNA interactions and their study by UVVisible, fluorescence spectroscopies and cyclic voltammetry, J. Photochem. Photobiol. B 124 (2013) 1-19;

c) P. Pandya, M.D.M. Islam, G.S. Kumar, B. Jayaram, S. Kumar, DNA minor groove binding of small molecules: experimental and computational evidence, J. Chem. Sci. 122 (2010) 247-257;

d) A. Paul, S. Bhattacharya, Chemistry and biology of DNA - binding small molecules, Curr. Sci. 102 (2012) 212-232.

[4] a) B. Armitage, Photocleavage of nucleic acids, Chem. Rev. 98 (1998) 1171-1200;

b) M. Kar, A. Basak, Design, synthesis, and biological activity of unnatural enediynes and related analogues equipped with $\mathrm{pH}$-dependent or phototriggering devices, Chem. Rev. 107 (2007) 2861-2890;

c) B. Breiner, K. Kaya, S. Roy, W.-Y. Yang, I.V. Alabugin, Hybrids of amino acids and acetylenic DNA-photocleavers: optimizing efficiency and selectivity for cance phototherapy, Org. Biomol. Chem. 10 (2012) 3974-3987;

d) S. Bosi, T. Da Ros, G. Spalluto, M. Prato, Fullerene derivatives: an attractive tool for biological applications, Eur. J. Med. Chem. 38 (2003) 913-923

e) M. Rajendran, Quinones as photosensitizer for photodynamic therapy: ROS generation, mechanism and detection methods, Photodiagn. Photodyn. Ther. (2015), http://dx.doi.org/10.1016/j.pdpdt.2015.07.177.

[5] a) N. Chowdhury, S. Dutta, S. Dasgupta, N.D. Pradeep Singh, M. Baidya, S.K. Ghosh, Synthesis, photophysical, photochemical, DNA cleavage/binding and cytotoxic properties of pyrene oxime ester conjugates, Photochem. Photobiol. Sci. 11 (2012) 1239-1250

b) J.R. Hwu, S.-C. Tsay, S.C. Hong, Y.-J. Leu, C.-F. Liu, S.-S.P. Chou, Oxime esters of anthraquinone as photo-induced DNA-cleaving agents for single- and doublestrand scissions, Tetrahedron Lett. 44 (2003) 2957-2960

c) J.R. Hwu, S.-C. Tsay, S.C. Hong, M.-H. Hsu, C.-F. Liu, S.-S.P. Chou, Relationship between structure of conjugated oxime esters and their ability to cleave DNA, Bioconjug. Chem. 24 (2013) 1778-1783.

[6] a) P.J. Bindu, K.M. Mahadevan, N.D. Satyanarayan, T.R. Ravikumar Naik, Synthesis and DNA cleavage studies of novel quinoline oxime esters, Bioorg. Med. Chem. 22 (2012) 898-900;

b) J.R. Hwu, J.-R. Yang, S.-C. Tsay, M.-H. Hsu, Y.-C. Chen, S.-S.P. Chou, Photo-induced DNA cleavage by (heterocyclo)carbonyl oxime esters of anthraquinone, Tetrahedron Lett. 49 (2008) 3312-3315;

c) S.-S.P. Chou, J.-C. Juan, S.-C. Tsay, K.P. Huang, J.R. Hwu, Oxime esters of 2,6 diazaanthracene-9,10-dione and 4,5-diazafluoren-9-one as photo-induced DNA-Cleaving agents, Molecules 17 (2012) 3370-3382.

[7] P. Karamtzioti, A. Papastergiou, J.G. Stefanakis, A.E. Koumbis, I. Anastasiou, M. Koffa K.C. Fylaktakidou, $O$-benzoyl pyridine aldoxime and amidoxime derivatives: novel efficient DNA photo-cleavage agents, Med. Chem. Commun. 6 (2015) 719-726.

[8] a) E.A. Theodorakis, X. Xiang, M. Lee, T. Gibson, On the mechanism of photo-induced nucleic acid cleavage using $\mathrm{N}$-aroyloxy-2-thiopyridones, Tetrahedron Lett. 39 (1998) 3383-3386;

b) E.A. Theodorakis, K.M. Wilcoxen, $\mathrm{N}$-aroyloxy-2-thiopyridones as efficient oxygen-radical generators: novel time-controlled DNA photocleaving reagents, Chem. Commun. 1927-1928 (1996): (c) P. Blom, A.X. Xiang, D. Kao, E.A. Theodorakis, Design, synthesis, and evaluation of $\mathrm{N}$-aroyloxy-2-thiopyridones as DNA Photocleaving reagents, Bioorg. Med. Chem. 7 (1999) 727-736.

[9] a) C. O'Brien, The rearrangement of ketoxime 0 -sulfonates to amino ketones (the Neber rearrangement), Chem. Rev. 64 (1964) 81-89;

b) T. Ooi, M. Takahashi, K. Doda, K. Maruoka, Asymmetric induction in the Neber rearrangement of simple ketoxime sulfonates under phase-transfer conditions: experimental evidence for the participation of an anionic pathway, J. Am. Chem. Soc. 124 (2002) 7640-7641;

c) S. Sakamoto, T. Inokuma, Y. Takemoto, Organocatalytic asymmetric Neber reaction for the synthesis of $2 \mathrm{H}$-azirine carboxylic esters, Org. Lett. 13 (2011) 6374-6377.

[10] a) Y. Yamamoto, H. Hasegawa, H. Yamataka, Dynamic path bifurcation in the Beckmann reaction: support from kinetic analyses, J. Organomet. Chem. 76 (2011) 4652-4660;

b) Z. Dua, Z. Li, Y. Gu, J. Zhang, Y. Deng, FTIR study on deactivation of sulfonyl chloride functionalized ionic materials as dual catalysts and media for Beckmann rearrangement of cyclohexanone oxime, J. Mol. Catal. A Chem. 237 (2005) 80-85;

c) F.-Y. Piao, Y.-Z. Xie, W.-B. Zhang, W. Zhang, R.-B. Han, High-yield method for the preparation of 1,3,4,5-tetrahydro-7-methoxy-2H-1-benzazepin-2-one with excellent regio and stereoselectivity, Synth. Commun. 43 (2013) 1920-1930;

d) J. Gui, Y. Deng, Z. Hu, Z. Sun, A novel task-specific ionic liquid for Beckmann rearrangement: a simple and effective way for product separation, Tetrahedron Lett. 45 (2004) 2681-2683.

[11] a) D. Pavlović, A. Fajdetić, S. Mutak, Novel hybrids of 15-membered 8a- and 9aazahomoerythromycin A ketolides and quinolones as potent antibacterials, Bioorg. Med. Chem. 18 (2010) 8566-8582;

b) R. Gaware, R. Khunt, L. Czollner, C. Stanetty, T. Da Cunha, D.V. Kratschmar, A. Odermatt, P. Kosma, U. Jordis, D. Claben-Houben, Synthesis of new glycyrrhetinic acid derived ring A azepanone, 29-urea and 29-hydroxamic acid derivatives as selective 11b-hydroxysteroid dehydrogenase 2 inhibitors, Bioorg. Med. Chem. 19 (2011) 1866-1880.

[12] a) X. Yu, G. Ding, Z. Gao, J. Zha, H. Xu, Natural-product-based insecticidal agents 16. Semisynthesis of C7-oxime sulfonate ester derivatives of obacunone as insecticidal agents against Mythimna separata Walker, Heterocycles 90 (2015) 1367-1374;

b) A. El-Faham, Y.A. Elnakdy, S.A.M. El Gazzar, M.M.A. El-Rahman, S.N. Khattab, Synthesis, characterization and anti-proliferation activities of novel cyano oximino sulfonate esters, Chem. Pharm. Bull. 62 (2014) 373-378;

c) A. Mastrolorenzo, A. Scozzafava, C.T. Supuran, The antifungal activity of sulfonylated/carboxylated acetyloxime may be due to inhibition derivatives of dibenzo-1,4-dioxine-2- of lanosterol-14 $\alpha$-demethylase, J. Enzym. Inhib. 15 (2000) 557-569;

d) W.A. Remers, G.J. Gibs, M.J. Weiss, Bisoxime sulfonates and bisquaternary hydrazones, J. Med. Chem. 10 (1967) 274-277.

[13] a) M. Shirai, M. Tsunooka, Photoacid and photobase generators: prospects and their use in the development of polymeric photosensitive systems, Bull. Chem. Soc. Jpn. 71 (1998) 2483-2507;

b) T. Shinozuka, M. Shirai, M. Tsunooka, Polymers as sulfonic acid generator on irradiation at 146 nm, Eur. Polym. J. 37 (2001) 1625-1634;

c) H. Yamato, T. Asakura, Y. Nishimae, A. Matsumoto, J. Tanabe, J.-L. Birbaum, P. Murer, T. Hintermann, M. Ohwa, Oxime sulfonate chemistry for advanced microlithography, J. Photopolym. Sci. Technol. 20 (2007) 637-642.

[14] a) K.C. Fylaktakidou, D.J. Hadjipavlou-Litina, K.E. Litinas, E. Varella, D.N. Nicolaides, Recent developments in the chemistry and in the biological applications of amidoximes, Curr. Pharm. Des. 14 (2008) 1001-1047;

b) D.N. Nicolaides, K.C. Fylaktakidou, K.E. Litinas, G.K. Papageorgiou, D. HadjipavlouLitina, 1,3-Cycloaddition Reactions of 2-oxo-2H-[1]benzopyran-4-carbonitrile Noxide. Synthesis of several new 4-substituted coumarins, J. Heterocycl. Chem. 35 (1998) 619-625.

[15] a) D.N. Nicolaides, D.R. Gautam, K.E. Litinas, C. Manouras, K.C. Fylaktakidou, Reactions of 2-(methoxyimino)benzene-1-ones with a-alkyl-ethoxycarbonylmethylene(triphenyl) phosphoranes, Tetrahedron 57 (2001) 9469-9474;

b) D.D.R. Gautam, J. Protopapas, K.C. Fylaktakidou, K.E. Litinas, D.N. Nicolaides, K. Tsoleridis, Unexpected one-pot synthesis of new polycyclic coumarin[4,3-c]pyridine derivatives via tandem hetero-Diels-Alder and 1,3 dipolar cycloaddition reaction, Tetrahedron Lett. 50 (2009) 448-451;

c) D.N. Nicolaides, K.C. Fylaktakidou, K.E. Litinas, D. Hadjipavlou-Litina, Synthesis and biological evaluation of several coumarin-4-carboxamidoxime and 3-(coumarin-4-yl)-1,2,4-oxadiazole derivatives, Eur. J. Med. Chem. 33 (1998) 715-724.

[16] a) D.N. Nicolaides, K.E. Litinas, I. Vrasidas, K.C. Fylaktakidou, Thermal transformation of arylamidoximes in the presence of phosphorous ylides. Unexpected formation of 3-aryl-5-arylamino-1,2,4-oxadiazoles, J. Heterocycl. Chem. 41 (2004) 499-503;

b) D.N. Nicolaides, K.E. Litinas, T. Papamehael, H. Grzeskowiak, D.R. Gautam, K.C. Fylaktakidou, An easy transformation of 2-amino-2-(hydroxyimino)acetates to carbamoylformamidoximes, Synthesis (2005) 407-410;

c) K.C. Fylaktakidou, K.E. Litinas, A. Saragliadis, S.G. Adamopoulos, D.N. Nicolaides, Synthesis of oxadiazoloquinoxaline, oxathiadiazoloquinoxaline and oxadiazolobenzothiazine derivatives, J. Heterocycl. Chem. 43 (2006) 579-583.

[17] a) M. Ispicoudi, K.E. Litinas, K.C. Fylaktakidou, A convenient synthesis of 5-aminosubstituted-1,2,4-oxadiale derivatives via reactions of amidoximes with carbodiimides, Heterocycles 75 (2008) 1321-1328;

b) M. Ispicoudi, M. Amvrazis, C. Kontogiorgis, A.E. Koumbis, K.E. Litinas, D.J. Hadjipavlou-Litina, K.C. Fylaktakidou, Convenient synthesis and biological profile of 5-amino-substituted 1,2,4-oxadiazole derivatives, Eur. J. Med. Chem. 45 (2010) 5635-5645; 
c) I. Doulou, C. Kontogiorgis, A.E. Koumbis, E. Evgenidou, D. Hadjipavlou-Litina, K.C. Fylaktakidou, Synthesis of stable aromatic and heteroaromatic sulfonylamidoximes and evaluation of their antioxidant and lipid peroxidation activity, Eur. J. Med. Chem. 80 (2014) 145-153.

[18] J. Lalevée, X. Allonas, J.-P. Fouassier, M. Shirai, M. Tsunooka, Photocleavage processes in an iminosulfonate derivative usable as photoacid in resist technology, Chem. Lett. 32 (2003) 178-179.

[19] J. Marmur, A procedure for the isolation of deoxyribonucleic acid from microorganisms, J. Mol. Biol. 3 (1961) 208-218.

[20] M.F. Reichmann, S.A. Rice, C.A. Thomas, P. Doty, A further examination of the molecular weight and size of desoxypentose nucleic acid, J. Am. Chem. Soc. 76 (1954) 3047-3053.

[21] K. Huang, F.G. Merced, M. Ortiz-Marciales, H.J. Meléndez, W. Correa, M. De Jesús, Highly enantioselective borane reduction of heteroaryl and heterocyclic ketoxime ethers catalyzed by novel spiroborate ester derived from diphenylvalinol: application to the synthesis of nicotine analogues, J. Organomet. Chem. 73 (2008) 4017-4026

[22] a) J.D. Ha, S.J. Lee, S.Y. Nam, S.K. Kang, S.Y. Cho, J.H. Ahn, J.-K. Choi, Efficient synthesis of 2-imidazol-2-ylacetates, Tetrahedron Lett. 47 (2006) 6201-6204;

b) M. Ghiaci, K. Bakhtiari, Microwave-assisted rapid dehydration of aldoximes to nitriles on a solid support, Synth. Commun. 31 (2001) 1803-1807.

[23] A. Wolfe, G. Shimer, T. Meehan, Polycyclic aromatic hydrocarbons physically intercalate into duplex regions of denatured DNA, Biochemistry 26 (1987) 6392-6396.

[24] J.R. Lakowicz, Principles of Fluorescence Spectroscopy, third ed. Springer, New York, 2006.

[25] a) H.R.P. Naik, H.S.B. Naik, T.R. Ravikumar, T.R.R. Naik, T. Aravinda, D.S. Lamani, H.R. Naika, 2-thieno/selenopyrano[2,3-b]quinolines: microwave-induced one-pot synthesis, DNA binding, and photocleavage studies, Phosphorus Sulfur Silicon 184 (2009) 2583-2593;

b) S.V. Kovalenko, I.V. Alabugin, Lysine-enediyne conjugates as photochemically triggered DNA double-strand cleavage agents, Chem. Commun. 1444 - 1446 (2005);

c) W.-Y. Yang, S. Roy, B. Phrathep, Z. Rengert, R. Kenworthy, D.A.R. Zorio, I.V. Alabugin, Engineering pH-gated transitions for selective and efficient doublestrand DNA photocleavage in hypoxic tumors, J. Med. Chem. 54 (2011) 8501-8516.

[26] H.-G. Korth, A.G. Neville, J. Lusztyk, Direct spectroscopic detection of sulfonyloxyl radicals and first measurements of their absolute reactivities, J. Phys. Chem. 94 (1990) 8835-8839.
[27] a) P.E. Nielsen, C. Jeppesen, M. Egholm, O. Buchardt, Photochemical cleavage of DNA by nitrobenzamides linked to 9-aminoacridine, Biochemistry 27 (1998) 6338-6343;

b) P.E. Nielsen, M. Egholm, T. Koch, J.B. Christensen, O. Buchardt, Photolytic cleavage of DNA by nitrobenzamido ligands linked to 9-aminoacridines gives DNA polymerase substrates in a wavelength-dependent reaction, Bioconjug. Chem. 2 (1991) 57-66;

c) R. Hurley, A.C. Testa, Triplet-state yield of aromatic nitro compounds, J. Am Chem. Soc. 90 (1968) 1949-1952:

d) I. Saito, M. Takayama, Photoactivatable DNA-cleaving amino acids: highly sequence-selective DNA photocleavage by novel L-lysine derivatives, J. Am. Chem. Soc. 117 (1995) 5590-5591.

[28] a) C.J. Yeom, Y. Goto, Y. Zhu, M. Hiraoka, H. Harada, Microenvironments and cellular characteristics in the micro tumor cords of malignant solid tumors, Int. J. Mol. Sci. 13 (2012) 13949-13965;

b) O. Tridan, C.M. Galmarini, K. Patel, I.F. Tannock, Drug resistance and the solid tumor microenvironment, J. Natl. Cancer Inst. 99 (2007) 1441-1454.

[29] F. Dimiza, F. Perdih, V. Tangoulis, I. Turel, D.P. Kessissoglou, G. Psomas, Interaction of copper(II) with the non-steroidal anti-inflammatory drugs naproxen and diclofenac: synthesis, structure, DNA- and albumin-binding, J. Inorg. Biochem. 105 (2011) 476-489.

[30] E.C. Long, J.K. Barton, On demonstrating DNA intercalation, Acc. Chem. Res. 23 (1990) 271-273.

[31] P. Zivec, F. Perdih, I. Turel, G. Giester, G. Psomas, Different types of copper complexes with the quinolone antimicrobial drugs ofloxacin and norfloxacin: structure, DNAand albumin-binding, J. Inorg. Biochem. 117 (2012) 35-47.

[32] A. Tarushi, S. Perontsis, A.G. Hatzidimitriou, A.N. Papadopoulos, D.P. Kessissoglou, G. Psomas, Copper(II) complexes with the non-steroidal anti-inflammatory drug tolfenamic acid: structure and biological features, J. Inorg. Biochem. 149 (2015) 68-79.

[33] D.P. Heller, C.L. Greenstock, Fluorescence lifetime analysis of DNA intercalated ethidium bromide and quenching by free dye, Biophys. Chem. 50 (1994) 305-312.

[34] G. Zhao, H. Lin, S. Zhu, H. Sun, Y. Chen, Dinuclear palladium(II) complexes containing two monofunctional $[\mathrm{Pd}(\mathrm{en})(\text { pyridine }) \mathrm{Cl}]^{+}$units bridged by Se or S. Synthesis, characterization, cytotoxicity and kinetic studies of DNA-binding, J. Inorg. Biochem. 70 (1998) 219-226.

[35] A. Papastergiou, S. Perontsis, P. Gritzapis, A.E. Koumbis, M. Koffa, G. Psomas, K.C. Fylaktakidou, Evaluation of $O$-alkyl and aryl sulfonyl aromatic and heteroaromatic amidoximes as novel potent DNA photo-cleavers, Photochem. Photobiol. Sci. (2016), http://dx.doi.org/10.1039/c5pp00439j. 